\title{
PENGARUH KEPEMIMPINAN KEPALA PESANTREN DAN MOTIVASI TERHADAP KEDISIPLINAN SERTA IMPLIKASINYA PADA KINERJA USTADZ DI PONDOK PESANTREN DI KOTA SERANG
}

\author{
Usep $^{1}$ Furtasan Ali Yusuf ${ }^{2}$ Basrowi $^{3}$ \\ ${ }^{123}$ Universitas Bina Bangsa \\ usepsetiawan86@gmail.com
}

\begin{abstract}
ABSTRAK
Penelitian ini bertujuan untuk mengetahui pengaruh kepemimpinan kepala pesantren dan motivasi terhadap kedisiplinan serta implikasinya pada kinerja ustadz di pondok pesantren di kota serang metode penelitian yang digunakan adalah deskriptif, (definisi metode deskriptif). Penelitian jenis ini dimaksudkan untuk mengangkat fakta, keadaan, variabel, dan fenomena-fenomena yang terjadi saat sekarang dan menyajikan apa adanya. Populasi dalam penelitian ini adalah seluruh guru/ustadz atau tenaga pengajar yang ada di lembaga pendidikan yang berbasis Boarding school di kota Serang sebanyak 444 orang. Adapun sampel yang digunakan sebanyak 215 orang. Maka penulis mengambil keputusan untuk menggunakan teknik pengambilan sampel yaitu metode analisis yang digunakan adalah SEM (Structural Equation Modelling). Hasil penelitian ini sebagai berikut Pengujian Hipotesis dilakukan berdasarkan hasil pengujian Inner Model (model struktural) yang meliputi output $r$-square, koefisien parameter dan t-statistik. Untuk melihat apakah suatu hipotesis itu dapat diterima atau ditolak diantaranya dengan memperhatikan nilai signifikansi antar konstrak, $t$ statistik, dan p-values. Pengujian hipotesis penelitian ini dilakukan dengan bantuan software SmartPLS (Partial Least Square) 3.0. Nilai-nilai tersebut dapat dilihat dari hasil bootstrapping. Rules of thumb yang digunakan pada penelitian ini adalah $t$-statistik $>1,96$ dengan tingkat signifikansi p-value 0,05 (5\%) dan koefisien beta bernilai positif.
\end{abstract}

Kata kunci : Kepemimpinan, Motivasi, Disiplin, dan Kinerja.

ABSTRACT

This study aims to determine the effect of the leadership of the Islamic boarding school principal and motivation on discipline and its implications for the performance of ustadz in Islamic boarding schools in the city of Serang. The research method used is descriptive, (descriptive method definition). This study prioritizes in-depth analysis of the data and facts found. This type of research is intended to raise facts, circumstances, variables, and phenomena that are happening now and present what they are. The population in this study were all teachers/ustadz or teaching staff in boarding school-based educational institutions in the city of Serang as many as 444 people. The samples used were 215 people. So the author made the decision to use a sampling technique, namely the analytical method used is SEM (Structural Equation Modeling). The results of this study are as follows. Hypothesis testing is carried out based on the results of testing the Inner Model (structural model) which includes r-square output, parameter coefficients and t-statistics. To see whether a hypothesis can be accepted or rejected, among others, by paying attention to the significance value between constructs, $t$ statistics, and p-values. The hypothesis testing of this research was carried out with the help of the SmartPLS (Partial Least Square) 3.0 software. These values can be seen from the bootstrapping results. The rule of thumb used in this study is t-statistic > 1.96 with a significance level of p-value $0.05(5 \%)$ and a positive beta coefficient. The value of this research hypothesis testing can be shown in the table and the results of this research model can be described as shown in the hypothesis testing carried out on all samples that have been obtained from the questionnaire.

Keywords: Leadership, Motivation, Discipline, and Performance. 
Prosiding The 1st National Conference on Applied Business, Education, \& Technology (NCABET)"

Unversitas Bina Bangsa 2021

DOI Article : 10.46306/ncabet.v1i1.40

Sumber Daya Manusia (SDM) adalah salah satu faktor yang sangat penting bahkan tidak dapat dilepaskan dari sebuah organisasi, baik institusi maupun perusahaan. SDM juga merupakan kunci yang dapat menentukan perkembangan suatu perusahaan. Pada hakikatnya, SDM berupa manusia yang dipekerjakan di sebuah organisasi sebagai penggerak, pemikir dan perencana untuk mencapai tujuan organisasi itu. (Tomcikova, et al, 2019).

Manajemen sumber daya manusia itu sendiri merupakan kombinasi antara kebijakan, praktik dan sistem yang mempengaruhi kebiasaan, tingkah laku dan performa karyawan dalam aktivitas berorganisasi (Adatsi, et al, 2020), dalam sebuah organisasi atau perusahaan, Manajemen Sumber Daya Manusia (MSDM) sangat erat kaitannya dengan SDM. MSDM sendiri memiliki manfaat dan fungsi yang banyak dan berguna dalam mengatur dan memberdayakan SDM untuk menunjang kemajuan suatu perusahaan atau organisasi.

Namun pada kenyataannya, kinerja guru di beberapa sekolah atau pondok pesantren masih kurang, hal ini terlihat pada syarat adminsitrasi sekolah yang masih belum terpenuhi secara keseluruhan. Berikut beberapa data kelengkapan administrasi sekolah pondok pesantren dikota Serang :

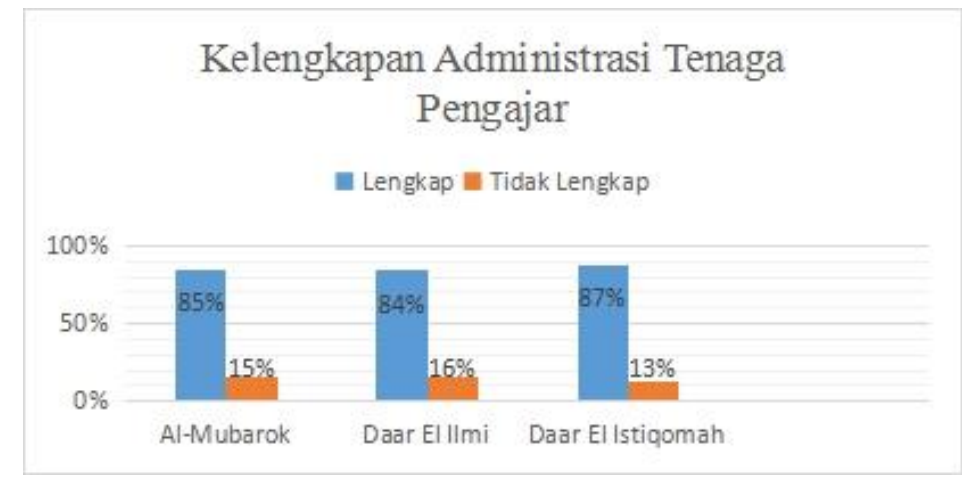

Grafik 1 Kelengkapan Administrasi Sekolah

Namun kenyataannya, tingkat kedisiplinan guru di beberapa sekolah atau pondok pesantren masih lemah, dalam hal ini, masih adanya guru atau tenaga pengajar yang masuk kelas tidak tepat waktu.

Berikut beberapa data tingkat kehadiran tenaga pengajar di pondok pesantren di Kota Serang: 


\section{Tingkat Kehadiran Tenaga Pengajar}

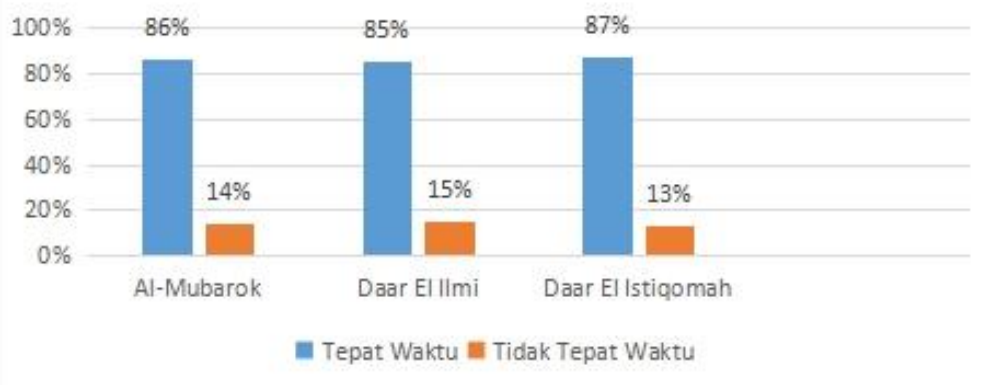

Sumber : Data Absensi Tenaga Pengajar pondok pesantren di Kota Serang

Grafik 2 Tingkat Kehadiran Tenaga Pengajar

\section{METODE PENELITIAN}

Metode penelitian yang peneliti gunakan adalah deskriptif, (definisi metode deskriptif) Penelitian ini mengutamakan analisa mendalam tentang data dan fakta yang ditemukan. Penelitian jenis ini dimaksudkan untuk mengangkat fakta, keadaan, variabel, dan fenomenafenomena yang terjadi saat sekarang dan menyajikan apa adanya.

\section{Populasi dan Sampel}

\section{Populasi}

Populasi merupakan seluruh komponen atau unsur dari suatu kajian yang dapat berupa individu atau objek serta ciri-cirinya (Sugiyono, 2009). Populasi dalam penelitian ini adalah seluruh guru/ustadz atau tenaga pengajar yang ada di lembaga pendidikan yang berbasis Boarding school di kota Serang sebanyak 444 orang.

Tabel. 1 Data Guru/ustadz yang ada di pondok pesantren di Kota Serang

\begin{tabular}{|l|l|}
\hline \multicolumn{1}{|c|}{ Nama Pondok Pesantren } & \multicolumn{1}{c|}{ Jumlah Guru/ustadz } \\
\hline Ponpes Al Mubarok & 92 Orang \\
\hline Ponpes Nurul Bantany & 62 Orang \\
\hline Ponpes Daar Ilmi & 53 Orang \\
\hline Ponpes Daar El Istiqomah & 47 Orang \\
\hline Ponpes Riadusholihin & 52 Orang \\
\hline Ponpes Ar Rahma & 75 Orang \\
\hline Darul Falah & 63 Orang - \\
\hline Total & 444 Orang \\
\hline
\end{tabular}

Sumber: Pondok Pesantren Di Kota Serang (2021)

\section{Sampel}

Sampel merupakan suatu bagian dari keseluruhan serta karakteristik yang dimiliki oleh sebuah Populasi. Apabila Populasi tersebut besar, sehingga para peneliti tentunya tidak 
Prosiding The 1st National Conference on Applied Business, Education, \& Technology (NCABET)"

Unversitas Bina Bangsa 2021

DOI Article : $10.46306 /$ ncabet.v1i1.40

memungkinkan untuk mempelajari keseluruhan yang ada pada populasi tersebut beberapa kendala yang akan di hadapi di antaranya seperti dana yang terbatas, tenaga dan waktu maka dalam hal ini perlunya menggunakan sampel yang di ambil dari populasi itu. Selanjutnya, apa yang dipelajari dari sampel tersebut maka akan mendapatkan kesimpulan yang nantinya di berlakukan untuk Populasi (Sugiyono, 2008).

Indikator dalam penelitian ini terdiri dari 3 variabel bebas dan 1 variabel terikat, dimana keempat variabel tersebut ditotal memiliki 43 indikator, sehingga sampel yang diperlukan berdasarkan rumus Hair diatas adalah:

$$
n=5 \times 43=215
$$

Berdasarkan perhitungan diatas jumlah sampel minimum yang akan diambil sejumlah 215 orang.

\section{HASIL DAN PEMBAHASAN}

Tabel 2 Uji Validitas dengan Loading Factor

\begin{tabular}{|l|l|l|l|l|}
\hline & Disiplin & Kepemimpinan & Kinerja & Motivasi \\
\hline D1 & 0.885 & & & \\
\hline D10 & 0.734 & & & \\
\hline D3 & 0.968 & & & \\
\hline D4 & 0.873 & & & \\
\hline D5 & 0.825 & & & \\
\hline D6 & 0.876 & & & \\
\hline D7 & 0.783 & & & \\
\hline D8 & 0.707 & & & \\
\hline D9 & 0.774 & & 0.846 & \\
\hline KJ1 & & & 0.758 & \\
\hline KJ10 & & & 0.790 & \\
\hline KJ11 & & & & \\
\hline KJ12 & & & & \\
\hline KJ2 & & & & \\
\hline
\end{tabular}


Prosiding The 1st National Conference on Applied Business, Education, \& Technology (NCABET)" Unversitas Bina Bangsa 2021

DOI Article : 10.46306/ncabet.v1i1.40

\begin{tabular}{|l|l|l|l|l|}
\hline & Disiplin & Kepemimpinan & Kinerja & Motivasi \\
\hline KJ3 & & & 0.752 & \\
\hline KJ4 & & & 0.793 & \\
\hline KJ5 & & & 0.795 & \\
\hline KJ6 & & & 0.753 & \\
\hline KJ7 & & & 0.710 & \\
\hline KJ9 & & & 0.760 & \\
\hline KP1 & & 0.802 & & \\
\hline KP10 & & 0.734 & & \\
\hline KP2 & & 0.794 & & \\
\hline KP3 & & 0.809 & & \\
\hline KP4 & & 0.738 & & \\
\hline KP5 & & 0.777 & & \\
\hline KP6 & & 0.724 & & \\
\hline KP7 & & 0.745 & & 0.754 \\
\hline KP8 & & 0.755 & & 0.7703 \\
\hline KP9 & & & & 0.756 \\
\hline M1 & & & & \\
\hline M10 & & & & \\
\hline M11 & & & & \\
\hline M2 & & & & \\
\hline M3 & & & & \\
\hline M4 & & & & \\
\hline M5 & & & & \\
\hline M6 & & & & \\
\hline M7 & & & & \\
\hline M8 & & & & \\
\hline M9 & & & & \\
\hline
\end{tabular}


Tabel 3 Average Variance Extracted

\begin{tabular}{|l|l|}
\hline & $\begin{array}{l}\text { Average Variance Extracted } \\
\text { (AVE) }\end{array}$ \\
\hline Disiplin & $\mathbf{0 . 6 9 5}$ \\
\hline Kepemimpinan & $\mathbf{0 . 5 9 4}$ \\
\hline Kinerja & $\mathbf{0 . 5 8 4}$ \\
\hline Motivasi & $\mathbf{0 . 5 8 1}$ \\
\hline
\end{tabular}

\section{Discriminant validity Cross Loading}

Nilai cross loading menunjukkan besarnya korelasi antara setiap konstrak dengan indikatornya dan indikator dari konstrak blok lainnya. Suatu model pengukuran memiliki discriminant validity yang baik apabila korelasi antara konstrak dengan indikatornya lebih tinggi daripada korelasi dengan indikator dari konstrak blok lainnya. Setelah dilakukan pengolahan data dengan menggunakan SmartPLS 3.0 hasil.

Tabel 4 Discriminant validity Cross Loading

\begin{tabular}{|c|c|c|c|c|}
\hline & isiplin & Kepemimpinan & Kinerja & Motivasi \\
\hline D1 & 0.885 & 0.385 & 0.554 & 0.555 \\
\hline D10 & 0.734 & 0.305 & 0.476 & 0.468 \\
\hline D2 & 0.968 & 0.368 & 0.584 & 0.585 \\
\hline D3 & 0.873 & 0.358 & 0.575 & 0.598 \\
\hline D4 & 0.878 & 0.332 & 0.523 & 0.504 \\
\hline D5 & 0.825 & 0.241 & 0.607 & 0.614 \\
\hline D6 & 0.876 & 0.307 & 0.584 & 0.575 \\
\hline D7 & 0.783 & 0.303 & 0.496 & 0.507 \\
\hline D8 & 0.707 & 0.213 & 0.402 & 0.417 \\
\hline D9 & 0.774 & 0.303 & 0.479 & 0.471 \\
\hline KJ1 & 0.532 & 0.209 & 0.846 & 0.777 \\
\hline KJ10 & 0.416 & 0.199 & 0.729 & 0.702 \\
\hline KJ11 & 0.428 & 0.147 & 0.758 & 0.722 \\
\hline KJ12 & 0.408 & 0.181 & 0.790 & 0.699 \\
\hline KJ2 & 0.541 & 0.305 & 0.750 & 0.764 \\
\hline KJ3 & 0.484 & 0.178 & 0.752 & 0.689 \\
\hline KJ4 & 0.557 & 0.247 & 0.793 & 0.712 \\
\hline KJ5 & 0.497 & 0.152 & 0.795 & 0.746 \\
\hline KJ6 & 0.483 & 0.180 & 0.753 & 0.684 \\
\hline KJ7 & 0.452 & 0.152 & 0.710 & 0.672 \\
\hline KJ8 & 0.523 & 0.135 & 0.760 & 0.738 \\
\hline
\end{tabular}


Prosiding The 1st National Conference on Applied Business, Education, \& Technology (NCABET)" Unversitas Bina Bangsa 2021

DOI Article : $10.46306 /$ ncabet.v1i1.40

\begin{tabular}{|c|c|c|c|c|}
\hline & isiplin & Kepemimpinan & Kinerja & Motivasi \\
\hline KJ9 & 0.521 & 0.202 & 0.723 & 0.689 \\
\hline KP1 & 0.294 & 0.802 & 0.179 & 0.193 \\
\hline KP10 & 0.236 & 0.734 & 0.149 & 0.156 \\
\hline KP2 & 0.298 & 0.794 & 0.146 & 0.152 \\
\hline KP3 & 0.344 & 0.809 & 0.296 & 0.317 \\
\hline KP4 & 0.181 & 0.738 & 0.116 & 0.120 \\
\hline KP5 & 0.287 & 0.777 & 0.162 & 0.179 \\
\hline KP6 & 0.257 & 0.724 & 0.213 & 0.199 \\
\hline KP7 & 0.292 & 0.821 & 0.250 & 0.262 \\
\hline KP8 & 0.329 & 0.745 & 0.204 & 0.206 \\
\hline KP9 & 0.314 & 0.755 & 0.141 & 0.169 \\
\hline M1 & 0.468 & 0.185 & 0.748 & 0.770 \\
\hline M10 & 0.432 & 0.177 & 0.643 & 0.709 \\
\hline M11 & 0.415 & 0.143 & 0.699 & 0.757 \\
\hline M2 & 0.539 & 0.300 & 0.705 & 0.732 \\
\hline M3 & 0.481 & 0.217 & 0.690 & 0.754 \\
\hline M4 & 0.558 & 0.281 & 0.739 & 0.789 \\
\hline M5 & 0.481 & 0.165 & 0.649 & 0.703 \\
\hline M6 & 0.494 & 0.181 & 0.708 & 0.756 \\
\hline M7 & 0.505 & 0.193 & 0.732 & 0.773 \\
\hline M8 & 0.523 & 0.168 & 0.794 & 0.827 \\
\hline M9 & 0.460 & 0.193 & 0.750 & 0.807 \\
\hline
\end{tabular}

\section{Composite Reliability Dan Cronbach's Alpha}

Kriteria keputusan uji reliabilitas dengan composite reliability dapat dilihat sebagai berikut:

a. Jika nilai composite reliability $>0.7$, maka item kuisioner terssebut reliabel.

b. Jika nilai composite reliability $<0.7$, maka item kuisioner terebut tidak reliabel.

Berikut merupakan hasil dari perhitungan composite reliability.

Tabel 5 Composite Reliability

\begin{tabular}{|c|l|l|l|l|}
\hline & $\begin{array}{l}\text { Cronbach's } \\
\text { Alpha }\end{array}$ & rho_A & $\begin{array}{l}\text { Composite } \\
\text { Reliability }\end{array}$ & $\begin{array}{l}\text { Average } \\
\text { Variance } \\
\text { Extracted } \\
\text { (AVE) }\end{array}$ \\
\hline Disiplin & 0.950 & 0.956 & 0.958 & 0.695 \\
\hline epemimpinan & 0.924 & 0.931 & 0.936 & 0.594 \\
\hline Kinerja & 0.935 & 0.936 & 0.944 & 0.584 \\
\hline Motivasi & 0.928 & 0.929 & 0.938 & 0.581 \\
\hline
\end{tabular}




\section{Uji Reliabilitas dengan Cronbach's Alpha}

Kriteria keputusan uji reliabilitas dengan Cronbach's alpha dapat dilihat sebagai berikut:

a. Jika nilai Cronbach's alpha >0.7, maka item kuisioner tersebut reliabel.

b. Jika nilai Cronbach's alpha $<0.7$, maka item kuisioner tersebut tidak reliabel.

Berikut merupakan hasil dari perhitungan composite reliability berdasarkan Berdasarkan hasil perhitungan nilai Cronbach's alpha seperti yang ditunjukkan pada tabel diatas, dapat diketahui bahwa nilai Cronbach's alpha semua konstruk lebih besar dari 0.7, yang berarti bahwa semua kontstruk tersebut reliabel.

\section{Analisis Variant (R2 ) atau Uji Determinasi}

Analisis Variant (R2 ) atau Uji Determinasi yaitu untuk mengetahui besar pengaruh variabel independen terhadap variabel dependen tersebut, nilai dari koefisien determinasi dapat ditunjukkan

Tabel 6 Analisis Variant (R2) atau Uji Determinasi

\begin{tabular}{|l|l|l|}
\hline & R Square & $\begin{array}{c}\text { R } \\
\text { Adjusted }\end{array}$ \\
\hline Disiplin & 0.456 & 0.451 \\
\hline Kinerja & 0.884 & 0.882 \\
\hline
\end{tabular}

\subsection{Uji Struktural Model (Hipotesis)}

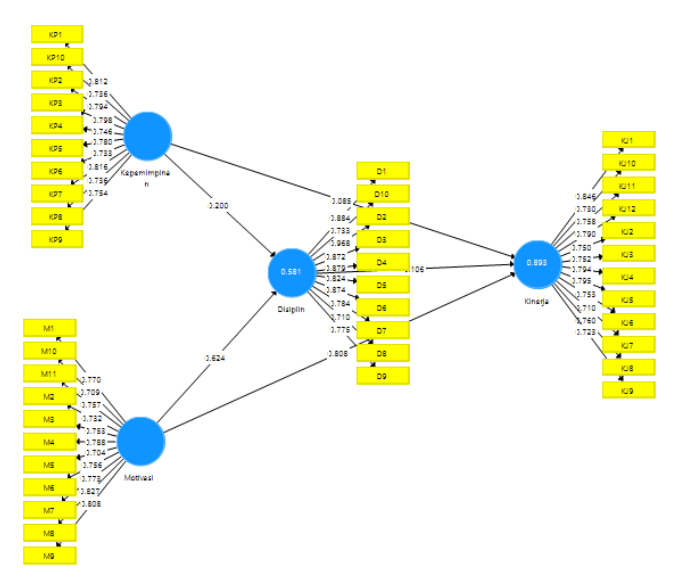




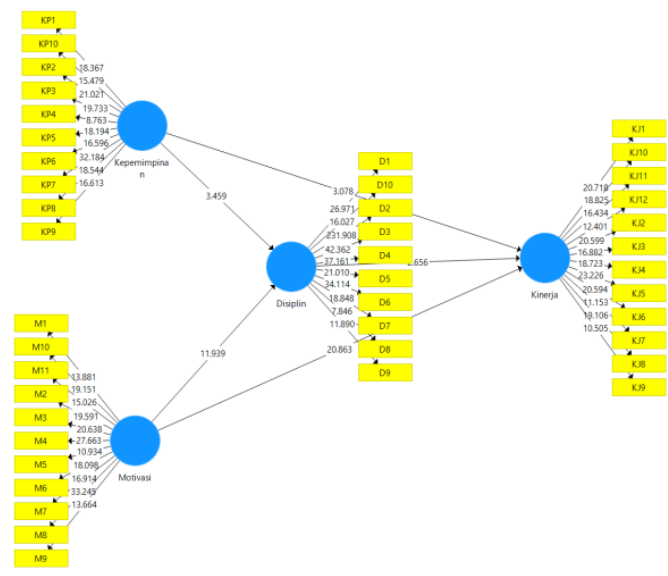

Gambar 2 Uji signifikansi Model

Pengujian Hipotesis dilakukan berdasarkan hasil pengujian Inner Model (model struktural) yang meliputi output r-square, koefisien parameter dan t-statistik. Untuk melihat apakah suatu hipotesis itu dapat diterima atau ditolak diantaranya dengan memperhatikan nilai signifikansi antar konstrak, t-statistik, dan p-values. Pengujian hipotesis penelitian ini dilakukan dengan bantuan software SmartPLS (Partial Least Square) 3.0. Nilai-nilai tersebut dapat dilihat dari hasil bootstrapping. Rules of thumb yang digunakan pada penelitian ini adalah t-statistik >1,96 dengan tingkat signifikansi p-value 0,05 (5\%) dan koefisien beta bernilai positif. Nilai pengujian hipotesis penelitian ini dapat ditunjukan pada Tabel dan untuk hasil model penelitian ini dapat digambarkan seperti tampak pada

Pengujian hipotesis dilakukan terhadap seluruh sampel yang telah didapatkan dari kuisioner. Pengujian hipotesis dilakukan dengan menggunakan software SmartPLS 3.0 dan hasilnya sebaga berikut.

Tabel 7 Uji Hipotesis

\begin{tabular}{|l|l|l|l|l|}
\hline & $\begin{array}{l}\text { Original } \\
\text { Sample (O) }\end{array}$ & $\begin{array}{l}\text { Standard } \\
\text { Deviation } \\
(\text { STDEV })\end{array}$ & $\begin{array}{l}\text { T Statistics } \\
(\mid \mathrm{O} / \text { STDEV })\end{array}$ & P Values \\
\hline emimpinan -> Disiplin & 0.200 & 0.054 & 3.459 & 0.000 \\
\hline ivasi -> Disiplin & 0.624 & 0.051 & 11.939 & 0.000 \\
\hline emimpinan -> Kinerja & 0.085 & 0.019 & 3.078 & 0.000 \\
\hline ivasi -> Kinerja & 0.808 & 0.024 & 20.863 & 0.000 \\
\hline plin -> Kinerja & 0.106 & 0.1 & 2.656 & 0.000 \\
\hline & & & & \\
\hline
\end{tabular}




\section{KESIMPULAN DAN SARAN}

\section{Kesimpulan}

Berdasarkan hasil analisis data dan pembahasan dapat disimpulkan:

1. Kepemimpinan secara langsung berpengaruh terhadap Disiplin ustadz di Pondok Pesantren se Kota Serang.

2. Motivasi secara langsung berpengaruh terhadap Disiplin ustadz di Pondok Pesantren se Kota Serang.

3. Kepemimpinan secara langsung berpengaruh terhadap Kinerja ustadz di Pondok Pesantren se Kota Serang.

4. Motivasi secara langsung berpengaruh terhadap Kinerja ustadz di Pondok Pesantren se Kota Serang..

5. Disiplin secara langsung berpengaruh terhadap Kinerja ustadz di Pondok Pesantren se Kota Serang..

6. Kepemimpinan mempunyai pengaruh tidak langsung yang signifikan terhadap kinerja ustads melalui disiplin ustadz di Pondok Pesantren se Kota Serang..

7. Motivasi mempunyai pengaruh tidak langsung yang signifikan terhadap kinerja ustadz melalui disiplin ustadz di Pondok Pesantren se Kota Serang.

\section{Saran}

Berdasarkan simpulan dan implikasii teoritis dan praktis, beberapa saran penelitian ini dapat diuraikan sebagai berikut.

1. Pimpinan pesantren hendaknya menyuguhkan gaya kepemimpinan yang baik seperti kepemimpinan yang demokratis dan transformasional, dalam rangka menghadapi perkembangan IT yang serba canggih yang harus diikuti beriringan dengan perkembangan pesantren yang siap melabeli dirinya sebagai pesantren modern.

2. Untuk peneliti yang akan datang, diharapkan dapat melakukan penelitian dengan lingkup yang lebih luas atau meneliti kinerja ustadz dengan menggunakan variabel lain seperti literasi teknologi, kelengkapan sumber belajar di pesantren, sarana dan prasarana laboratorium di pesantren, efektivitas pembelajaran science, dan lain-lain. 
Prosiding The 1st National Conference on Applied Business, Education, \& Technology (NCABET)"

Unversitas Bina Bangsa 2021

DOI Article : $10.46306 /$ ncabet.v1i1.40

\section{UCAPAN TERIMA KASIH}

Penulis ucapkan terima kasih kepad Tim Panitia NCBET yang telah menginisiasi acara serta terima kasih kepada Bpk. Dr. Furtasan Ali Yusuf selaku Rektor UNIBA yang telah mendorong kami untuk selalu aktif dalam melakukan

\section{DAFTAR PUSTAKA}

\section{Sumber Buku}

Eko Putro Widoyoko. 2015. Teknik Penyusunan Instrumen Penelitian. Yogyakarta: Pustaka Belajar Celeban Timur.

Hani Handoko. 2014. Manajemen Personalia \& Sumber Daya Manusia. Yogyakarta: BPFEYOGYAKARTA.

Husain Umar. 2008. Metode Penelitian untuk Skripsi dan Tesis Bisnis. Jakarta: PT Raja Grafindo Persada.

Mahmudi. 2016. Buku Pedoman dan Tata Tertib Pesantren. Serang: Kopontren.

Malayu Hasibuan. 2005. Manajemen Sumber Daya Manusia. Jakarta: PT Bumi Aksara. Marwansyah. 2016. Manajemen Sumber Daya Manusia. Bandung: Alfabeta.

Moeherjono. 2014. Pengukuran Kinerja Berbasis Kompetensi. Jakarta: PT Raja Grafindo Persada.

Moh Nazir. 2005. Metode Penelitian. Jakarta: Ghalia Indonesia.

Ratna Rahmayanti.2016. Pengaruh Disiplin Kerja Terhadap Kinerja Guru. Yogyakarta. Reza Primadi. 2017. Pengaruh Kedisiplinan Terhadap Kinerja Karyawan. Riau.

Ridwan dan Sunarto. 2017. Pengantar Statistika. Bandung: Alfabeta.

Sugiono. 2016. Metode Penelitian Kuantitatif, Kualitatif R\&D. Bandung: Alfabeta.

Supardi. 2016. Kinerja Guru. Jakarta: PT Raja Grafindo Persada.

Sedarmayanti. 2017. Manajemen Sumber Daya Manusia. Bandung: PT Refika Aditama.

\section{Sumber Jurnal}

Abbas, Q., \& Yaqoob, S. (2009). Effect of Leadership Development on Employee Performance in Pakistan. Pakistan, 47(2), 269-292.

Azhary, S. A., Supahar, S., Kuswanto, K., Ikhlas, M., \& Devi, I. P. (2020). Relationship Between Behavior of Learning and Student Achievement in Physics Subject. Jurnal Pendidikan Fisika Indonesia, 16(1), 1-8. https://doi.org/10.15294/jpfi.v16i1.23096

Bilan, Y., Hussain, H. I., Haseeb, M., \& Kot, S. (2020). Sustainability and economic performance: role of organizational learning and innovation. Engineering Economics, 31(1), 93-103. https://doi.org/10.5755/j01.ee.31.1.24045 
Prosiding The 1st National Conference on Applied Business, Education, \& Technology (NCABET)"

Unversitas Bina Bangsa 2021

DOI Article : 10.46306/ncabet.v1i1.40

Bintari Kartika Sari. (2017). Desain Pembelajaran Model ADDIE dan Impelentasinya dengan Teknik Jigsaw. Prosiding Seminar Nasional Pendidikan : Tema "Desain Pembelajaran Di Era ASEAN Economic Community (AEC) Untuk Pendidikan Indonesia Berkemajuan ,”94-96, 87-102. http://eprints.umsida.ac.id/432/1/ARTIKEL Bintari Kartika Sari.pdf

Casmito, Achmad Rifai, R., \& Harlanu, M. (2020). The Effect of Academic Supervision and Teacher Participation in Subject Teacher's Meeting on Improving Teacher Performance of Islamic Junior High School. 443(Iset 2019), 143-146.

https://doi.org/10.2991/assehr.k.200620.028

Chen, C. H., Liu, J. H., \& Shou, W. C. (2018). How competition in a game-based science learning environment influences students' learning achievement, flow experience, and learning behavioral patterns. Educational Technology and Society, 21(2), 164-176.

Chen, Y. C. (2017). Empirical study on the effect of digital game-based instruction on students' learning motivation and achievement. Eurasia Journal of Mathematics, Science and Technology Education, 13(7), 3177-3187.

https://doi.org/10.12973/eurasia.2017.00711a

Chiou, C. C., Lee, L. T., Tien, L. C., \& Wang, Y. M. (2017). Analyzing the effects of various concept mapping techniques on learning achievement under different learning styles. Eurasia Journal of Mathematics, Science and Technology Education, 13(7), 3687-3708. https://doi.org/10.12973/eurasia.2017.00753a

Chu, S. K. W., Zhang, Y., Chen, K., Chan, C. K., Lee, C. W. Y., Zou, E., \& Lau, W. (2017). The effectiveness of wikis for project-based learning in different disciplines in higher education. Internet and Higher Education, 33, 49-60. https://doi.org/10.1016/j.iheduc.2017.01.005

Ery Haryanto, S. \& D. W. Y. K. (2020). The Relationship between Discipline, Responsibility , and Motivation Study to Study Achievement. 9(23), 64-70.

Fajrin, W. I. (2020). The Effect of Digitalization of School Data and Teacher Performance on Student Achievement at SD Muhammadiyah 2 Denpasar (Issue c).

Fitria, H., Mukhtar, M., \& Akbar, M. (2017). the Effect of Organizational Structure and Leadership Style on Teacher Performance in Private Secondary School. IJHCM (International Journal of Human Capital Management), 1(02), 101-112. https://doi.org/10.21009/ijhcm.012.12

Goldman, Z. W., Goodboy, A. K., \& Weber, K. (2017). College Students' Psychological Needs and Intrinsic Motivation to Learn: An Examination of Self-Determination Theory. Communication Quarterly, 65(2), 167-191. https://doi.org/10.1080/01463373.2016.1215338

Hailu, B. W. (2020). Assessment of Learning Organization Practice and Disciplines in Case of Sire District Public Health Office, Arsi Zone, Oromia Region, Ethiopia, 2018 : 
Prosiding The 1st National Conference on Applied Business, Education, \& Technology (NCABET)"

Unversitas Bina Bangsa 2021

DOI Article : 10.46306/ncabet.v1i1.40

Qualitative Case Study.

Hall, M. T., \& Marshall, J. E. (2015). Intrinsic and Extrinsic Motivation within the Context of Modern Education. November, 292-308. https://doi.org/10.4018/978-1-4666-96341.ch014

Hartinah, S., Suharso, P., Umam, R., Syazali, M., Lestari, B. D., Roslina, R., \& Jermsittiparsert, K. (2020). Teacher's performance management: The role of principal's leadership, work environment and motivation in Tegal City, Indonesia. Management Science Letters, 10(1), 235-246. https://doi.org/10.5267/j.msl.2019.7.038

Hernández-Serrano, M. J., \& Muñoz-Rodríguez, J. M. (2020). Interest in STEM disciplines and teaching methodologies. Perception of secondary school students and preservice teachers. Educar, 56(2), 369-386. https://doi.org/10.5565/REV/EDUCAR.1065

Monahan, B. J. (2020). TITLE : The Ways Teacher-Student Relationships in an Independent Study Setti ng Influence Student Achievement The Ways Teacher-Student Relationships in an Independent Study Setting Influence Student Achievement Beverly J . Monahan EDAD 698: Master's Cu.

Muhammad Rifa'i. (2018). Pengaruh Kepemimpinan Kepala Sekolah Terhadap Disiplin Kerja Guru Di Sd Negeri 060794 Kecamatan Medan Area. Jurnal Manajemen Pendidikan Dan Keislaman, 7(1), 1979-8075.

gers' leadership, compensation and benefits, and departments' performance: Evidence from upscale hotels in Australia: Leadership, compensation and performance. Journal of Hospitality and Tourism Management, 42(November 2018), 29-39. https://doi.org/10.1016/j.jhtm.2019.11.005

Payne, A. A., \& Welch, K. (2015). Restorative Justice in Schools: The Influence of Race on Restorative Discipline. Youth and Society, 47(4), 539-564. https://doi.org/10.1177/0044118X12473125

Peer, S., Journals, R., \& Publishing, B. (2021). Parental Involvement and Students ' Discipline in Twelve Years Basic Education Schools in Rwanda: A Case Study of Nyarugenge District Habyarimana Jean de Dieu \& Dr. Hesbon O . Andala ( PhD ) Parental Involvement and Students 'Discipline in Twelve Years. 4(1), 33-52.

Rabgay, T. (2018). The effect of using cooperative learning method on tenth grade students' learning achievement and attitude towards biology. International Journal of Instruction, 11(2), 265-280. https://doi.org/10.12973/iji.2018.11218a

Rahman, A., \& Ahmar, A. S. (2017). Relationship between learning styles and learning achievement in mathematics based on genders. World Transactions on Engineering and Technology Education, 15(1), 74-77. https://doi.org/10.26858/wtetev15i1y2017p7477

Riswanto, A., \& Aryani, S. (2017). Learning motivation and student achievement : description analysis and relationships both. COUNS-EDU: The International Journal of Counseling 
Prosiding The 1st National Conference on Applied Business, Education, \& Technology (NCABET)"

Unversitas Bina Bangsa 2021

DOI Article : 10.46306/ncabet.v1i1.40 and Education, 2(1), 42. https://doi.org/10.23916/002017026010

Rozi, A., Agustin, F., Hindriari, R., Rostikawati, D., \& Akbar, I. R. (2020). The Effect of Leadership on Employee Performance at PT. Stella Satindo in Jakarta. Humanities,Management and Science Proceedings, 1(1), 55-61.

Rustiani, R., Djafar, S., Rusnim, R., Nadar, N., Arwan, A., \& Elihami, E. (2019). Measuring Usable Knowledge: Teacher's Analyses of Mathematics for Teaching Quality and Student Learning. International Conference on Natural and Social Sciences (ICONSS) Proceeding Series, September, 239-245.

Salamon, T., \& Mesko, M. (2016). Can an ethical work climate influence payment discipline? Journal of Industrial Engineering and Management, 9(1), 73-89. https://doi.org/10.3926/jiem.1537

Saleem, F., Zhang, Y. Z., Gopinath, C., \& Adeel, A. (2020). Impact of Servant Leadership on Performance: The Mediating Role of Affective and Cognitive Trust. SAGE Open, 10(1). https://doi.org/10.1177/2158244019900562

Siahaan, Y. L. O., \& Meilani, R. I. (2019). Sistem Kompensasi dan Kepuasan Kerja Guru Tidak Tetap di Sebuah SMK Swasta di Indonesia. Jurnal Pendidikan Manajemen Perkantoran, 4(2), 141. https://doi.org/10.17509/jpm.v4i2.18008

Simatupang, A., \& Saroyeni, P. (2018). The Effect of Discipline, Motivation and Commitment to Employee Performance. IOSR Journal of Business and Management (IOSR-JBM), 20(6), 31-37. https://doi.org/10.9790/487X-2006013137

Steinberg, M. P., \& Garrett, R. (2015). Classroom Composition and Measured Teacher Performance: What Do Teacher Observation Scores Really Measure? Educational Evaluation and Policy Analysis, 38(2), 293-317. https://doi.org/10.3102/0162373715616249

Sullivan, F. R., \& Heffernan, J. (2016). Robotic construction kits as computational manipulatives for learning in the STEM disciplines. Journal of Research on Technology in Education, 48(2), 105-128. https://doi.org/10.1080/15391523.2016.1146563

Suratman, B., Wulandari, S. S., Nugraha, J., \& Narmaditya, B. S. (2020). Does teacher certification promote work motivation and teacher performance? A lesson from Indonesia. International Journal of Innovation, Creativity and Change, 11(10), 516-525.

Susanto, H. (2013). Faktor-faktor yang mempengaruhi kinerja guru sekolah menengah kejuruan. Jurnal Pendidikan Vokasi, 2(2), 197-212. https://doi.org/10.21831/jpv.v2i2.1028

Vlasenko, K., Chumak, O., Sitak, I., Lovianova, I., \& Kondratyeva, O. (2019). Training of mathematical disciplines teachers for higher educational institutions as a contemporary problem. Universal Journal of Educational Research, 7(9), 1892-1900. https://doi.org/10.13189/ujer.2019.070907 
Prosiding The 1st National Conference on Applied Business, Education, \& Technology (NCABET)"

Unversitas Bina Bangsa 2021

DOI Article : 10.46306/ncabet.v1i1.40

Walsh, B. M., \& Magley, V. J. (2020). Workplace civility training: understanding drivers of motivation to learn. International Journal of Human Resource Management, 31(17), 2165-2187. https://doi.org/10.1080/09585192.2018.1441164

Walters, S. R., Silva, P., \& Nikolai, J. (2017). Teaching, learning, and assessment: Insights into students' motivation to learn. Qualitative Report, 22(4), 1151-1168.

Wijayanti, Lilis Endang 1), Fran Sayekti2), Reschiwati3), D. P. 1). (2020). April 2020 Revised: 20. Journal International, 1(4), 560-571. https://doi.org/10.31933/DIJEMS

Wu, J. Y., Hsiao, Y. C., \& Nian, M. W. (2020). Using supervised machine learning on largescale online forums to classify course-related Facebook messages in predicting learning achievement within the personal learning environment. Interactive Learning Environments, 28(1), 65-80. https://doi.org/10.1080/10494820.2018.1515085 